\title{
ACYL HOMOSERINE LACTONE LACTONASE BACTERIA POTENTIAL AS BIOCONTROL AGENT OF SOFT ROT INFECTION
}

\author{
ERMA SURYANTI, ARIS TRI WAHYUDI, ALINA AKHDIYA and IMAN RUSMANA* \\ Department of Biology, Faculty of Mathematic and Natural Sciences, \\ Bogor Agricultural Univerisity, Bogor, Indonesia \\ Center for Agricultural Biotechnology and Genetic Resources Research and Development \\ (ICABIOGRAD), Cimanggu, West Java, Indonesia \\ *E-mail:irusmana@ipb.ac.id
}

Accepted 25 May 2020, Published online 30 June 2020

\begin{abstract}
The virulence gene expression of phytopathogenic bacteria, such as Dickeya dadantii is regulated by quorum sensing (QS) mechanism. The QS mechanism is induced by acyl homoserine lactone (AHL) that is universal autoinducer of Gram-negative bacteria. Degradation of AHL compound can be used to control the virulence of phytopathogenic bacteria. The enzyme of AHL lactonase is encoded by the aiiA gene and can degrade the lactone ring of AHL. This study was aimed to characterize aiiA gene encoding AHL lactonase from 20 isolates of shrimp pond and soil forest, Indonesia and examine the isolates ability to reduce violacein pigment of Chromobacterium violaceum and soft rot disease symptoms caused by $D$. dadantii. The results showed nine bacterial isolates (B4, B10, B11, B13, B14, B16, B17, B18 and B19) containing the aiiA gene encoding AHL lactonase. Based on 16S rRNA gene identification, 9 isolates had the highest similarity with Bacillus toyonensis, B. cereus, B. thuringiensis, B. mycoides and B. subtilis. These isolates had the capability to reduce the formation of violacein pigment and the symptoms of soft rot disease in potatoes. These results show that the AHL lactonase produced by these isolates can be used as Quorum Quenching (QQ) agent to inhibit the QS mechanism
\end{abstract}

Key words: Acyl-Homoserine lactone, lactonase, C. violaceum, D. dadantii, Quorum quencing

\section{INTRODUCTION}

Phytopathogenic bacteria can reduce agricultural and horticultural production of plants. Infection and colonization of the plants results in abnormal symptoms, such as spot, soft rot, cancer, or hormone imbalance, which lead to plant overgrowth, stunting, root branching, or death. These condition results in the lower quality and quantity of plants (Mansfield et al., 2012). Pseudomonas viridiflava, Pectobacterium carotovorum, and Dickeya spp. are responsible of soft rot disease in wide range of crops and ornamental plants (Reverchon \& Nasser, 2013). These bacteria can produce extracellular enzymes, such as protease, pectinase, and cellulose, as a virulence factor causing maceration of plant tissue. Dickeya spp. are a broad range spectrum phytopathogens, responsible in causing soft rot

\footnotetext{
* To whom correspondence should be addressed.
}

and wilt disease in carrot, banana, corn, tomato, sweet potato, cabbage, chrysanthemum, Begonia, Dahlia, Freesia, Hyacinthus, Iris, Kalanchoe dan Zantedeschia (Lee et al., 2002; Samson et al., 2005).

Virulence factor of some phytopathogenic bacteria are regulated through quorum sensing mechanisms (Defoirdt et al., 2004). Quorum sensing (QS) is a signaling system that occurs in pathogenic bacteria to sense its own population density and synchronize the expression of the virulence genes via secretion of small, diffusible signal molecules or autoinducers (AIs) (Fuqua \& Greenberg, 2002). QS can regulate the expression of genes associated with pathogenicity including biofilm formation and virulence of bacterial pathogens such as Pseudomonas aeruginosa, Staphylococcus aureus, Escherichia coli, and Erwinia spp. (Crepin et al., 2012). This signaling process or quorum sensing plays an important role in coordinating many physiological phenomena such as regulation of the expression of pathogenicity genes, formation of 
biofilm, bioluminescence, sporulation, antibiotic production, and formation of pigment such as violacein (Fuqua \& Greenberg, 2002). The QS mechanism depends on the density of bacterial cells that produced and accumulated signal molecules or autoinducers (AIs).

Based on the importance of the QS process, the anti-QS mechanism can be used as biocontrol for phytopathogenic bacteria. One of the anti-QS mechanisms is quorum quenching (QQ) through the degradation of $\mathrm{N}$-acyl homoserine lactones (AHLs) compounds using AHL lactonase enzyme. AHLs are universal autoinducer compounds of Gram-negative pathogenic bacteria such as Erwinia carotovora and Agrobacterium tumefaciens (Fuqua \& Greenberg, 2002). The disruption of the QS mechanism occurs so that virulence genes of pathogenic bacteria are not expressed (Czajkowski \& Jafra, 2009). The QQ mechanism is the environmental friendly mechanism because it suppress bacterial virulence without killing the pathogen (Zhang et al., 2019).

The successive quorum quenching mechanism against the infection of phytopathogenic bacteria was firstly reported by Dong et al. (2000). aiiA gene from Bacillus 24B01 had been expressed in E. carotovora SCG1 that producing AHL lactonase which decreased the AHL compound and extracellular pectinolytic enzyme production. This QQ process in E. carotovora (Pectobacterium caratovorum) SCG1 brought positive impact on the reduction of soft rot disease symptoms in potato, eggplant, cabbage, carrot, celery, cauliflower, and tobacco (Dong et al., 2000). Molina et al. (2003) reported that expressing of AHL lactonase from Bacillus spp. in Pseudomonas fluroscene P3 significantly reduced potato soft rot caused by Erwinia carotovora and crown gall of tomato caused by Agrobacterium tumefaciens. Several rhizospheric and phyllospheric bacteria that produce AHL lactonase has been known to control the pathogenic D. dadantii onset in potato and orchid (Khoiri et al., 2016; Sari et al., 2017; Satwika et al., 2017). Recent study found that QQ activity of Pseudomonas segetis P6 isolated from Salicornia europaea alleviated the soft rot disease symptoms caused by Dickeya solani, Pectobacterium atrosepticum, and $P$. carotovorum in potato and carrot (Rodriguez et al., 2020). Exploration and characterization of potential quorum quencher bacterial isolates should be developed to control the phytopathogenic bacteria. This study aimed to characterize AHL lactonase producing bacteria of 20 bacterial isolates originated from shrimp pond and forest soil, Indonesia and observe their capability to reduce violacein pigment formation of $C$. violaceum and soft rots symptoms of $D$. dadantii.

\section{MATERIAL AND METHODS}

\section{Materials}

Bacteria used in this study are 20 bacterial isolates that are isolated from shrimp pond sediment and forest soil, Indonesia. We used 20 bacteria without prior isolation, obtained from Dr. Iman Rusmana and Dr. Alina Akhdiya collection, coauthor of this journal, which was used in the previous research. C. violaceum and D. dadantii A3 were obtained from ICABIOGRAD Microbiology Laboratory, Biology Department, Faculty of Mathematics and Natural Sciences, IPB University, Indonesia collection. All bacteria were cultured in LB liquid medium at $28^{\circ} \mathrm{C}$.

\section{Bioassay of AHL-degrading activity}

The bioassay was determined using a disc diffusion assay based on Fitriyah et al. (2015). All bacteria were cultured in Luria Bertani Broth (LB). Then, bacterial culture was centrifuged at $16,000 \mathrm{~g}$ for $10 \mathrm{~min}$ and supernatant was filtered using 0.2 um membrane filter. As much as $20 \mu \mathrm{L}$ supernatant was dropped on a $6 \mathrm{~mm}$ paper disc. The disc was placed on a LB agar plate containing $1 \%$ of $C$. violaceum $\left(\mathrm{OD}_{600} 0.8\right)$. Plate was incubated at room temperature for $24 \mathrm{~h}$ and $20 \mu \mathrm{l}$ of sterile $\mathrm{dH}_{2} \mathrm{O}$ was used as control. AHL degradation activity was indicated and determined by measuring nonpurple zone diameter around paper disc. AHLdegradation index was calculated by the following formula:

$$
\text { AHL degradation index }=\frac{\begin{array}{c}
\text { non-purple zone diameter }- \\
\text { paper disc diameter }
\end{array}}{\text { paper disk diameter }} \times 100 \%
$$

\section{Detection of aiiA gene encoding AHL lactonase}

Genomic DNA extraction was performed by Presto $^{\mathrm{TM}}$ Mini gDNA procedure Bacteria Kit (Geneaid). The concentration and the purity of DNA were calculated using Nanodrop 2000 (Thermo Scientific Wilminton DE, USA). Amplification of aiiA gene from selected bacterial isolates was performed using an aiiAF primer (5'-GGA AGA TCT ATG ACA GTA AAG AAG CTT TAT TTC G-3') and aiiA R primer (5'-CATG CCA TCA TCA ACA AGA TAC TA TGA TGA TGT- 3') (Dong et al., 2000). The amplification was done with an initial denaturation step at $94^{\circ} \mathrm{C}$ for $2 \mathrm{~min}$, followed by 30 cycles of amplification at denaturation $95^{\circ} \mathrm{C}$ for $30 \mathrm{sec}$, annealing $55^{\circ} \mathrm{C}$ for $45 \mathrm{sec}$, elongation $72^{\circ} \mathrm{C}$ for $30 \mathrm{sec}$ and then followed by final elongation $72^{\circ} \mathrm{C}$ for $10 \mathrm{~min}$. The PCR products were sent to First Base, Malaysia for sequencing. The sequences were analyzed using Seqtrace and compared to aiiA 
gene database using the BLASTN and amino acid database using the BLASTX from the NCBI (www.ncbi.nlm.nih.gov). Phylogenetic analysis was performed using MEGA 5.05 with Neighbour Joining (NJ) method with bootstrap 1000 replication.

\section{Identification of bacterial isolates}

Amplification of 16S rRNA gene was performed by using primers of $63 \mathrm{f}$ (5'-CAG GCC CAC ATG TAA CAA GTC-3') and 1387r (5'-GGG CGG GTA WGT CAA GGC-3') (Marchesi et al., 1998). The amplification was done with an initial denaturation step at $95^{\circ} \mathrm{C}$ for $5 \mathrm{~min}$, followed by 30 cycles of amplification at $95^{\circ} \mathrm{C}$ for $1 \mathrm{~min}$ denaturation, annealing at $55^{\circ} \mathrm{C}$ for $1 \mathrm{~min}$, and extension at $72^{\circ} \mathrm{C}$ for $1.5 \mathrm{~min}$ with a final extension step at $72^{\circ} \mathrm{C}$ for 10 min then followed by final elongation $72^{\circ} \mathrm{C}$ for 10 minutes. The sequence results were analyzed as described earlier.

\section{Bioassay of violacein production}

A total of $30 \mathrm{~mL} \mathrm{LB}$ broth was inoculated with $1 \%$ C. violaceum $\mathrm{OD}_{660}=0.05$. About $300 \mu \mathrm{L}$ supernatant was added to LB broth containing $C$. violaceum followed by incubation for 24 and 48 hours at $27^{\circ} \mathrm{C}$. The production of violacein was measured by extracting the violacein pigment from the culture of $C$. violaceum (Choo et al., 2006). The positive control was $C$. violaceum culture without inoculation of the test bacterial supernatant. A total of $1.5 \mathrm{~mL}$ each $C$. violaceum culture was centrifuged at $16,000 \mathrm{~g}$ for $15 \mathrm{~min}$. The supernatant was removed and pellet was resuspended in $1.5 \mathrm{~mL}$ DMSO. Pellet was centrifuged at $16.000 \mathrm{~g}$ for 15 minutes. The violacein extracted in the supernatant was estimated by measuring OD at $585 \mathrm{~nm}$. Violacein unit was calculated as the ratio (OD585/ OD660), which gives an indication of violacein production per unit of growth (Chaudhari et al., 2004).

\section{Bioassay of anti-QS activity against Dickeya dadantii A3}

Bacterial isolates producing AHL-lactonase were tested for their ability to inhibit virulence of D. dadantii A3 using the method described by Dong et al. (2000). Potato tuber was surface sterilized by immersing in $70 \%$ ethanol for $1 \mathrm{~min}$ and sterile water for $3 \mathrm{~min}$. The potato tuber was then wounded $0.6 \mathrm{~cm}$ in depth on the centre part and soaked in bacterial cultures then, the wound was inoculated with $1 \mu \mathrm{L}$ of $D$. dadantii $\mathrm{A} 3\left(\mathrm{OD}_{660}=\right.$ 0.8). Symptoms of soft rot disease in potato tuber were observed after 24 hours of incubation at room temperature.

\section{RESULTS AND DISCUSSION}

\section{AHL degradation activity}

C. violaceum is the QS indicator bacteria due to its capablility to produce violacein pigment through QS mechanism. The violacein pigment formation of $C$. violaceum is determined by the concentration of N-hexanoyl homoserine lactone as an autoinducer compound (Morohoshi et al., 2008). Among 20 bacterial isolates, 9 isolates exhibited AHL degradation activity against $C$. violaceum (Table 1). The non-purple zone indicated the inhibition of violacein pigment production by C. violaceum (Figure 1).

The results suggested that the nine bacterial isolates produce AHL degrading enzymes. The nine bacterial isolates showed AHL degradation index in the range of 0.33-4.17 (Table 1). Highest value of inhibition zone was B16 with AHL degradation index as 4.17 (Figure 1; Table 1). B13 and B18 showed the lowest AHL degradation index of 0.33 (Figure 1; Table 1). Fitriyah et al. (2015) reported that 6 bacteria isolated from the agricultural land had an AHL degradation index in the range of 0.532.61. AHL degrading bacteria from various

Table 1. The N-hexanoyl homoserine lactone degradation index of bacterial supernatant indicated

\begin{tabular}{|c|c|c|c|}
\hline $\begin{array}{l}\text { Isolate } \\
\text { Code }\end{array}$ & Source & $\begin{array}{l}\text { Diameter of non-purple zone } \\
\text { formation }(\mathrm{mm})\end{array}$ & $\begin{array}{l}\text { AHL Degradation } \\
\text { Index }\end{array}$ \\
\hline B4 & Lampung Shrimp Pond & 16 & 1.67 \\
\hline B10 & Cangkuang Forest Sukabumi & 18 & 2.00 \\
\hline B11 & Cangkuang Forest Sukabumi & 14 & 1.33 \\
\hline B13 & Cangkuang Forest Sukabumi & 8 & 0.33 \\
\hline B14 & Cangkuang Forest Sukabumi & 23 & 2.83 \\
\hline B16 & Cangkuang Forest Sukabumi & 32 & 4.17 \\
\hline B17 & Cangkuang Forest Sukabumi & 9 & 0.5 \\
\hline B18 & Cangkuang Forest Sukabumi & 8 & 0.33 \\
\hline B19 & Cangkuang Forest Sukabumi & 13 & 1.17 \\
\hline
\end{tabular}




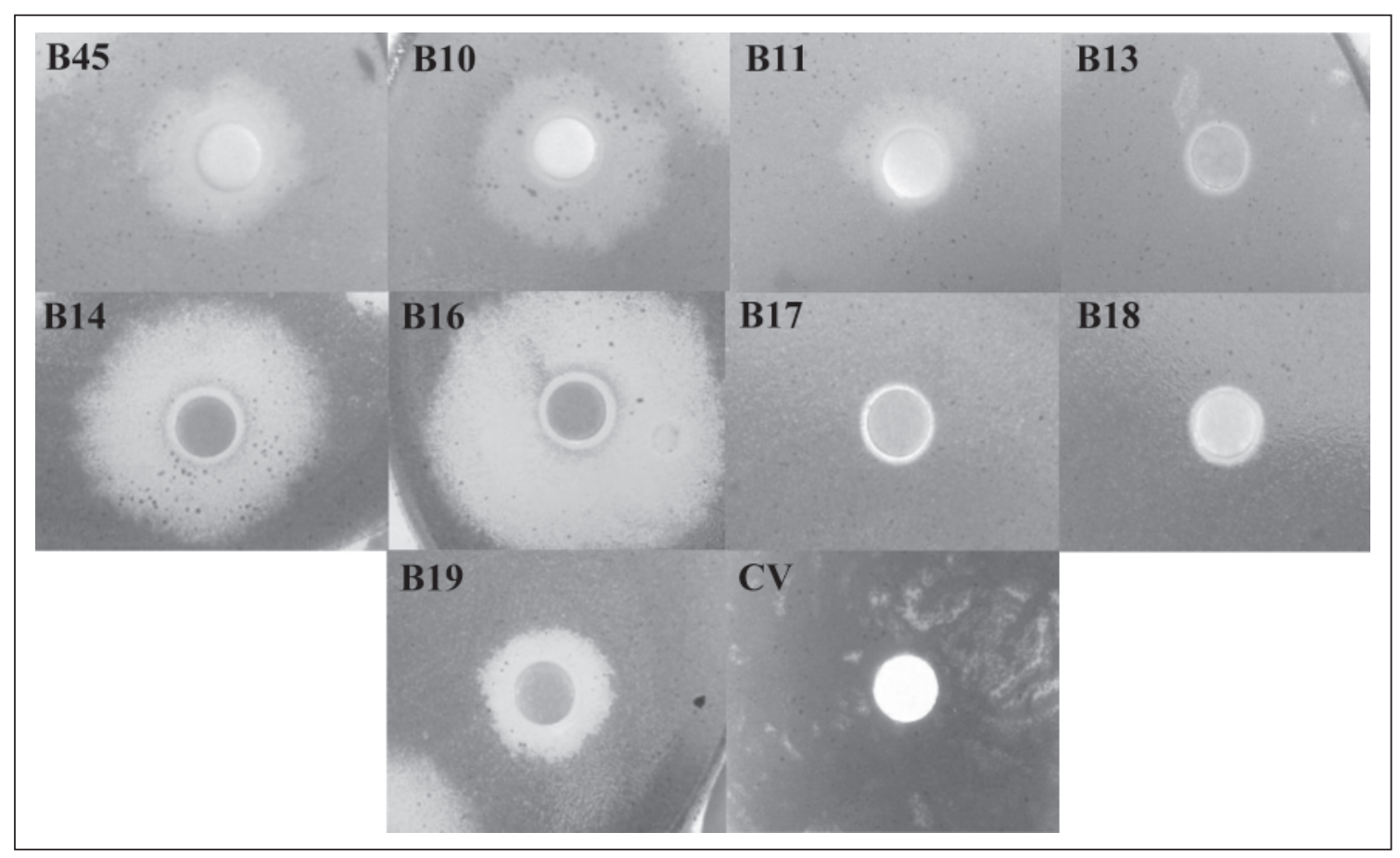

Fig. 1. Formation of non-purple zone around the paper disc soaked by supernatant of selected bacterial isolates. The symbols CV indicate negative control.

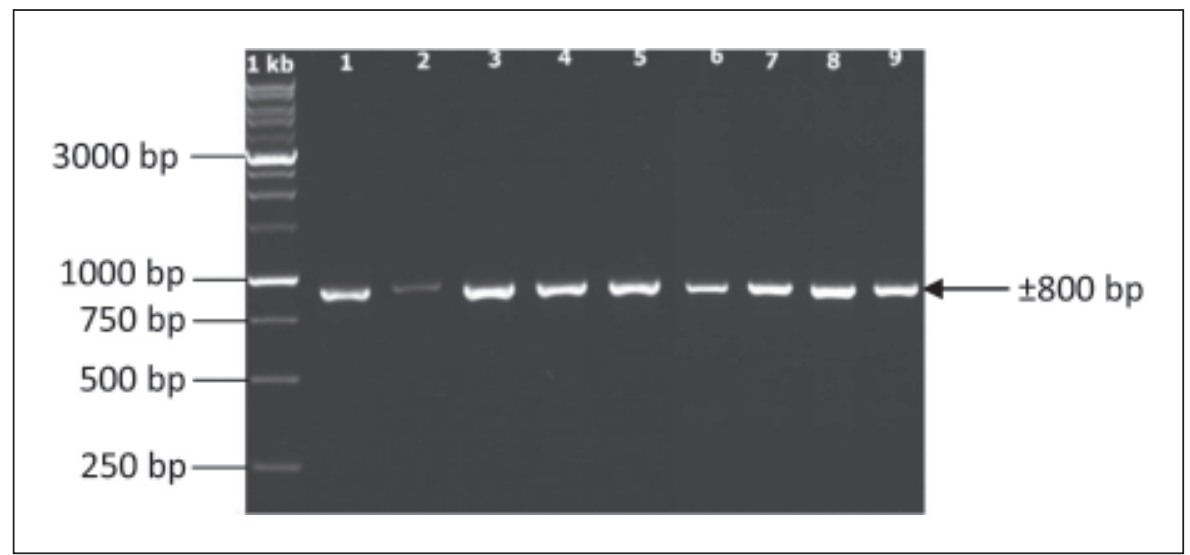

Fig. 2. PCR products ( $800 \mathrm{bp}$ ) of aiiA genes visualized on $0.8 \%$ agarose gel electrophoresis. M: 1 kb DNA marker; Lane 1, 2, 3, 4, 5, 6, 7, 8 and 9: indicating PCR products of of B4, $\mathrm{B} 10, \mathrm{~B} 11, \mathrm{~B} 13, \mathrm{~B} 14, \mathrm{~B} 16, \mathrm{~B} 17, \mathrm{~B} 18$, and $\mathrm{B} 19$ respectively.

rhizosphere and phylosphere samples in Indonesia were reported to have an AHL degradation index in the range of 0.077-3.08 (Satwika et al., 2017).

\section{aii $A$ gene of $\mathrm{AHL}$ degrading bacteria analysis}

The result showed that aiiA gene encoding AHL lactonase had amplified from all 9 bacterial isolates. These isolates had obtained AHL degrading activity based on bioassay using C. violaceum (Figure 2). Further amino acid analysis based on the aiiA sequences indicated high similarity to the amino acids of AHL lactonase from the Bacillus group such as B. thuringiensis, B. cereus, B. mycoides, and
B. wiedmannii with homology 96-99\% (Table 2). Phylogenetic tree based on the amino acid sequences of AHL lactonase of all the 9 AHL degrading bacteria showed that they had a close relationship with AHL lactonase of Bacillus group, however they had different clusters with the AHL lactonase produced by the Rhodococcus facians (Figure 3).

The AHL lactonase enzyme is a metallobetalactamase (metalloenzyme) that is able to hydrolyze the ester bond on the homoserine lactone ring of AHL and the acyl homoserine compound is not recognized as a signal molecule. It cannot bind 
Table 2. The amino acid sequence homology of AHL-degrading bacterial isolates

\begin{tabular}{|c|c|c|c|c|}
\hline $\begin{array}{l}\text { Bacterial } \\
\text { Isolate }\end{array}$ & Reference bacterial strain (Gene Bank Database) & $\begin{array}{l}\text { Identity } \\
\qquad \%)\end{array}$ & E-value & Acc. Number \\
\hline B4 & $\begin{array}{l}\text { MULTISPECIES: N-acyl homoserine lactone hydrolase } \\
\text { [Bacillus] }\end{array}$ & 99 & 0.0 & WP_000216574.1 \\
\hline B10 & $\mathrm{N}$-acyl homoserine lactonase [B. cereus] & 99 & 0.0 & WP_059303559.1 \\
\hline B11 & $\mathrm{N}$-acyl homoserine lactonase [Bacillus thuringiensis] & 97 & $8 e-177$ & WP_071731229.1 \\
\hline B13 & $\begin{array}{l}\text { MULTISPECIES: N-acyl homoserine lactonase } \\
\text { [Bacillus cereus group] }\end{array}$ & 96 & $1 e-176$ & WP_000216580.1 \\
\hline $\mathrm{B} 14$ & MULTISPECIES: N-acyl homoserine lactonase aiiA [Bacillus] & 96 & $6 e-174$ & WP_016111450.1 \\
\hline B16 & $\mathrm{N}$-acyl homoserine lactonase [Bacillus mycoides] & 93 & $2 e-167$ & WP_044438838.1 \\
\hline $\mathrm{B} 17$ & $\mathrm{~N}$-acyl homoserine lactonase [Bacillus weihenstephanensis] & 90 & $3 e-165$ & WP_070128835.1 \\
\hline B18 & N-acyl homoserine lactonase [Bacillus cereus] & 96 & $1 e-174$ & WP_017656305.1 \\
\hline B19 & N-acyl homoserine lactonase [Bacillus wiedmannii] & 97 & $2 e-176$ & WP_061677651.1 \\
\hline
\end{tabular}

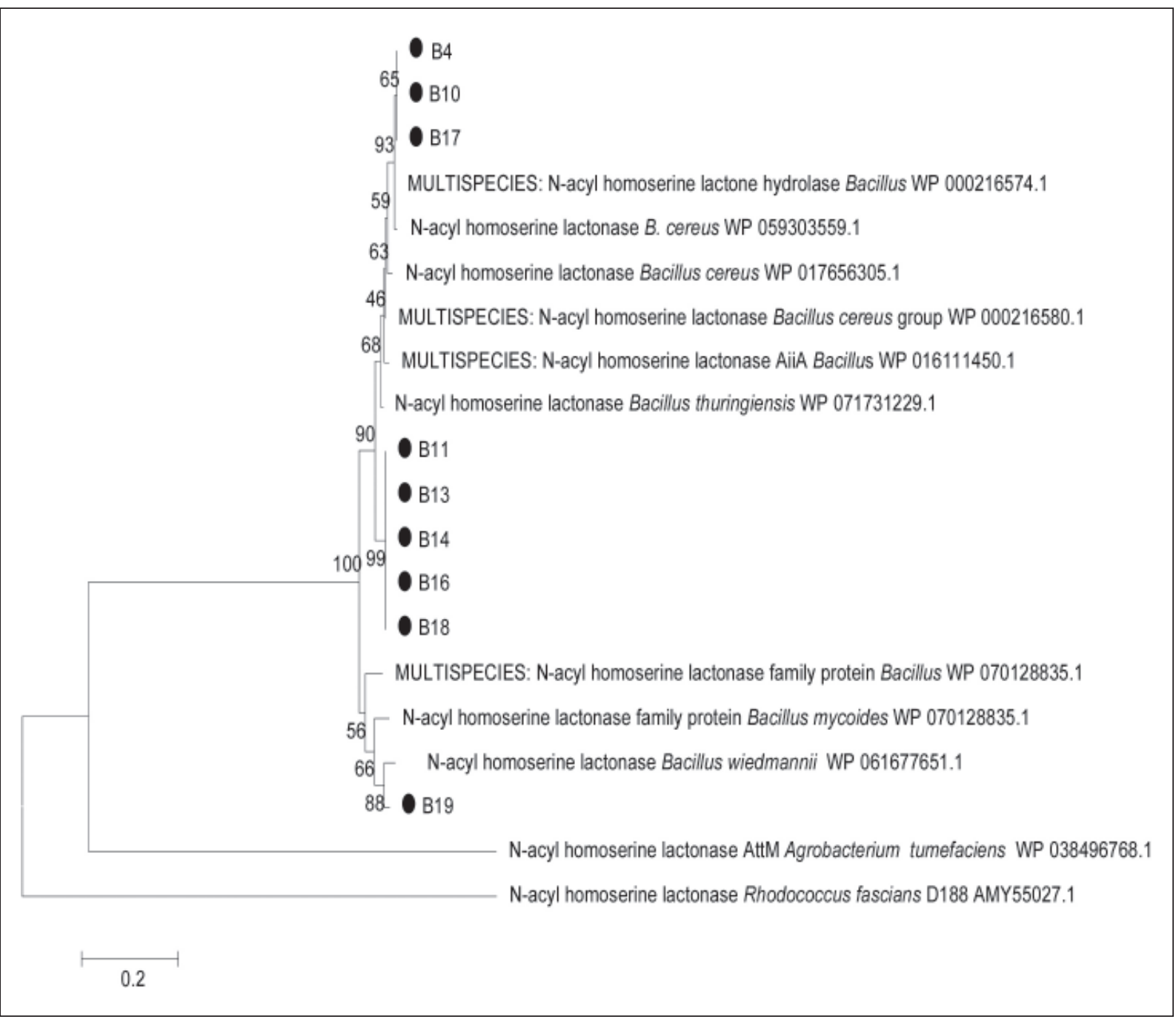

Fig. 3. Phylogenetic tree based on aiiA gene nucleotide sequences using maximum likelihood method (bootstrap 1000 replication). 
Table 3. Homology of $16 \mathrm{~S}$ rRNA gene sequence of $\mathrm{AHL}$ degrading bacteria isolate

\begin{tabular}{clccc}
\hline Isolate code & Reference species(Database Gene Bank) & Identity (\%) & E-value & Accession number \\
\hline B4 & Bacillus cereus strain EM20 & 100 & 99 & KJ612546.1 \\
B10 & Bacillus cereus strain MER140 & 100 & 99 & KT719718.1 \\
B11 & Bacillus cereus strain p20 & 100 & 98 & KX783605.1 \\
B13 & Bacillus thuringiensis strain SSA550 & 100 & 98 & KC534226.1 \\
B14 & Bacillus cereus strain EM6 & 100 & 99 & KJ612533.1 \\
B16 & Bacillus cereus strain EM5 & 100 & 99 & KJ612532.1 \\
B17 & Bacillus toyonensis strain BCT-7112 & 100 & 99 & NR121761.1 \\
B18 & Bacillus subtilis strain PJS & 100 & 99 & KU672511.1 \\
B19 & Bacillus mycoides strain WJB140 & 100 & 99 & KU877669.1 \\
\hline
\end{tabular}

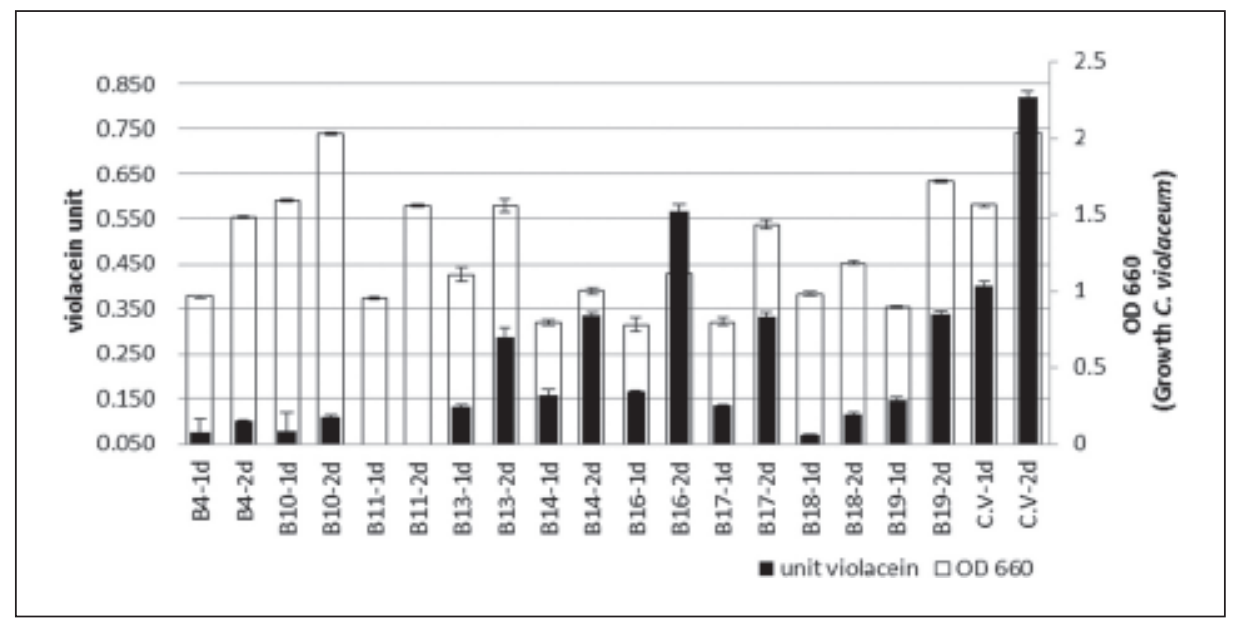

Fig. 4. Violacein production and growth of $C$. violaceum cultures treated with bacterial supernatant. $\mathrm{CV}=$ Control Treatment; B4, B10, B11, B13, B14, B16, B17, B18, B19 = treatment of supernatant bacterial code; $1 \mathrm{~d}=24$ hours incubation; $2 \mathrm{~d}=48$ hours incubation.

to the transcriptional regulatory protein, such as ExpR so that the degradation of AHL by the enzyme inhibits the QS mechanism. All genes regulated by the QS mechanism are not expressed such as the genes involve in virulence factors of bacterial phytophatogens (Defoirdt et al., 2004).

AHL lactonase from Bacillus spp. reported to have high activity to degrade AHL with various side-chain groups and acyl chain lengths such as C4-HSL (N-butyryl-dl-homoserine lactone), C6-HSL (N-hexanoyl-dl-homoserine lactone), C8-HSL (N-octanoyl-dl-homoserine lactone), C10-HSL (N-decanoyl-dl-homoserine lactone) and C12-HSL (N-dodecanoyl-dl-homoserine lactone) (Wang et al., 2004; Torres et al., 2013).

\section{Identification of AHL-lactonase producing bacteria}

Isolates displaying positive results for aiiA gene were further identified through amplification of $16 \mathrm{~S}$ rRNA gene. Blast-N analysis of 16S rRNA gene sequences showed that these isolates were closely related to genus Bacillus i.e. B. thuringiensis, $B$. cereus, B. mycoides, B. subtilis, and B. toyonensis
(Table 3). Dong et al. (2002) reported that the aiiA gene was found in Bacillus species including $B$. subtilis, B. cereus, B. mycoidies, and some strains of $B$. thuringiensis. Huma et al. (2011) reported that the aiiA gene encoding the AHL lactonase enzyme is widespread among Bacillus sp. strains including Bacillus cereus, B. thuringiensis, B. anthracis and B. mycoides.

\section{Inhibition of violacein formation produced by C. violaceum}

The violacein pigment formation in $C$. violaceum is regulated by QS mechanisms (Hoshino, 2011). This ability can be calculated based on the violacein units, which can be measured at 585/660 $\mathrm{nm}$ (Chaudhari et al., 2004). The former OD presented violacein pigment, while the latter represented bacterial growth. The result showed that each bacterial supernatant tested had different ability to inhibit the violacein pigment formation. In general, bacterial supernatant was able to reduce formation of the pigment after 24 hours and 48 hours incubation (Figure 4). The addition of B4, B11, B13, B14, B16, B17, B18 and B19 supernatant 
also showed inhibition violacein formation and growth suppression of $C$. violaceum. The growth inhibition of $C$. violaceum was observed from OD $660 \mathrm{~nm}$ that was lower than the one without bacterial supernatant addition (control) (Figure 4). This result indicated that 8 AHL degradation isolates were also capable in producing antimicrobial compounds. The result showed that B. cereus B10 supernatant addition did not suppress $C$. violaceum growth. In consequence, $C$. violaceum growth with the B10 supernatant addition was same as control (Figure 4). The result showed that the capability of $B$. cereus $\mathrm{B} 10$ in violacein formation inhibition occurs through quorum quenching mechanism. Khori et al. (2017) reported that inoculated bacterial supernatants of EKK10 and B13 could inhibit violacein pigment and growth inhibition of $C$. violaceum based on $660 \mathrm{~nm}$ value.

\section{Anti-quorum sensing activity against Dickeya dadantii A3}

Dickeya dadantii (ex: Erwinia chrysanthemi) is a plant pathogenic bacterium generating soft rot diseases on various plants, including chicory, arabidopsis, orchids, saintpaulia, cabbages, and carrots (Lamas et al., 2009). The anti-QS activity test was performed on potato tubers to determine the ability of the isolates in suppression of soft rot disease caused by $D$. dadantii A3. Expression of the genes associated with virulence factors on $D$. dadantii is regulated by quorum sensing mechanism, using 3-oxo-C6-HSL as an autoinducer (Czajkowski \& Jafra, 2009).

The results showed that 9 AHL lactonase producing bacterial isolates were successful in suppressing the soft rot disease caused by $D$. dadantii A3 compared with control (Figure 5 and Figure 6). The results showed that soft rot symptom was not detected in potato after B. cereus B11, $B$. cereus $\mathrm{B} 13, B$. thuringiensis $\mathrm{B} 14$ inoculation. These bacterial isolates have the highest suppression of $D$. dadantii infection. This inhibition was not only impacted by the AHL lactonase, which was produced by these bacteria. The three bacteria also have antibiosis activity based on the $C$. violaceum growth analysis (Figure 4). Satwika et al. (2017) reported that AHL degrading bacteria also had antibiosis activity. In contrast to the other bacterial isolates, B. cereus B10 had no antibiotic activity based on the $C$. violaceum growth analysis. This result indicated the soft rot symptom reduction on potato occurs through the QQ mechanism. The AHL lactonase produced by nine bacteria could interfere QS D. dadantii in consequence of pectinolytic enzyme gene unsuccessfully expressed. Bacillus spp. known as biocontrol agent with various modes of action, including: antibiosis through antimicrobial compounds production such as lipopeptides, antibiotics, and bacteriocins; quorum sensing discruption through inactivation of acyl-homoserine lactones (Raaijmakers et al., 2010; Gerayeli et al., 2018). Krzyzanowska et al. (2012) reported the

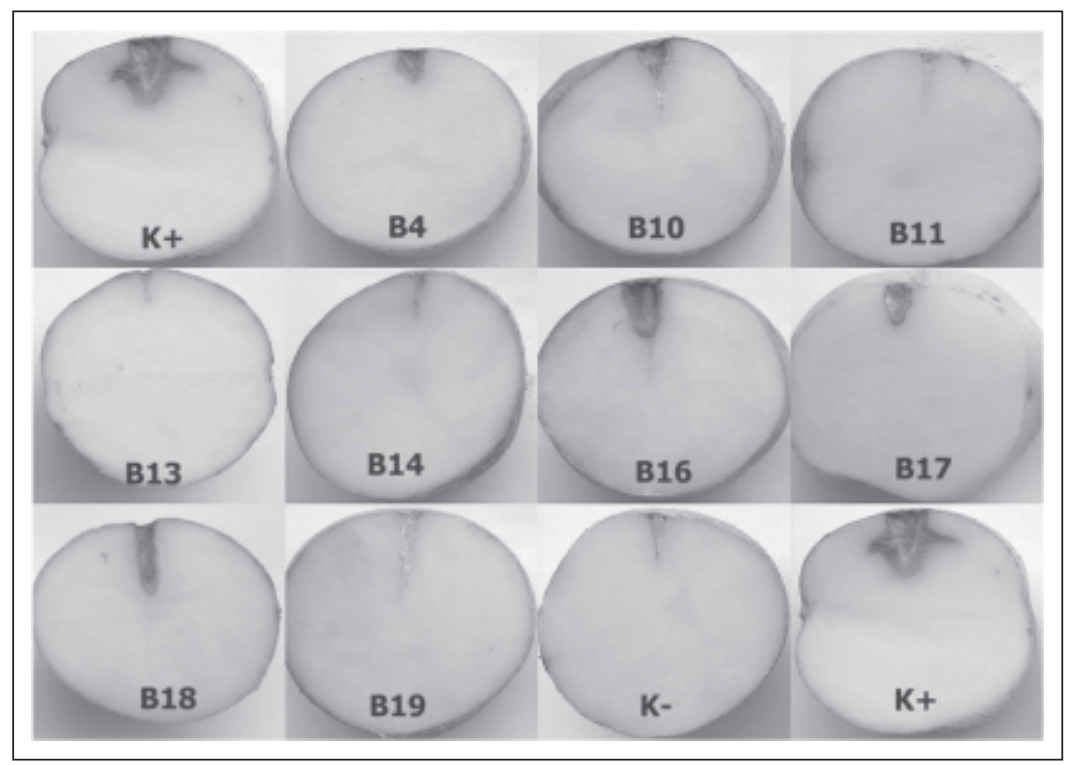

Fig. 5. Inhibition of soft rot symptoms caused by $D$. dadantii $A 3$ on potato tubers due to degradation of AHL signal by the bacterial isolates.

$\mathrm{K}+=$ positive control (inoculated with $D$. dadantii $\mathrm{A} 3$ only); $\mathrm{K}-=$ negative control (inoculated with sterilewater); and B4, B10, B11, B13, B14, B16, B17, B18, B19 = treatment of potato tuber with bacterial supernatant before inoculation with $D$. dadantii $\mathrm{A} 3$. 


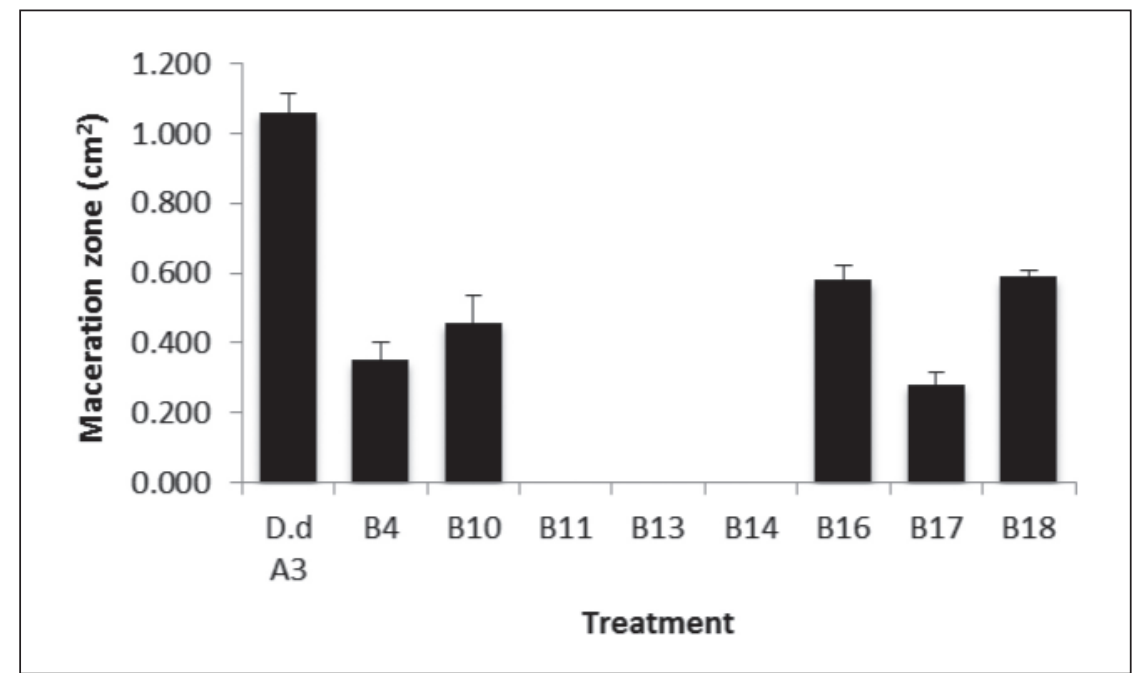

Fig. 6. The tuber maceration zone of soft rot symptoms caused by $D$. dadantii $A 3$ on potato tubers due to degradation of AHL signal by the bacterial isolates.

D.d A3 = positive control (inoculated by D. dadantii A3 only); and B4, B10, B11, B13, B14, $\mathrm{B} 16, \mathrm{~B} 17, \mathrm{~B} 18, \mathrm{~B} 19=$ treatment of potato tuber by soaking in the bacterial isolate cultures (indicate by the symbol, respectively) before they were inoculated with $D$. dadantii A3.

role of qourum quenching mechanism is more effective than the antimicrobial mechanism against Pectobacterium spp. and Dickeya spp. infection in potato and chicory.

Recent study reported that transgenic tobacco, Amorphophallus konjac, and cabbage expressing AHL lactonase were able to reduce soft rot disease caused by Erwinia carotovora SCG1 (Dong et al., 2001; Dong et al., 2002; Ban et al., 2009). The AHL lactonase of Bacillus subtilis BSI was used to control the soft rot symptoms caused by Erwinia carotovora var. carotovora on potato (Pan et al., 2008). Our results also supported the previous research that reported AHL lactonase producing bacteria had potential to inhibit the virulence of D. dadantii. Many pathogenic bacteria perform quorum sensing to regulate the expression of virulence genes. Therefore, in order to control plant phatogenic bacteria it was suggested to interfere their bacterial quorum sensing system by quorum quenching for treating or preventing the phytopatogenic bacterial infection.

\section{CONCLUSION}

The nine bacterial isolates namely $\mathrm{B} 4, \mathrm{~B} 10, \mathrm{~B} 11$, B13, B14, B16, B17, B18, and B19 were successfully characterized as AHL lactonase degrading bacteria. These isolates have capability to inhibit violacein pigment formation of $C$. violaceum and reduce soft rot disease on potato tuber of $D$. dadantii infection. The nine AHL lactonase degrading bacteria could be developed as biocontrol agents through quorum quenching mechanism approach.

\section{ACKNOWLEDGEMENTS}

The authors would like to thank Department of Biology, Bogor Agricultural Univerisity and Center for Agricultural Biotechnology and Genetic Resources Research for supporting this research.

\section{REFERENCES}

Ban, H., Chai, X., Lin, Y., Zhou, Y., Peng, D., Zhou, Y., Zou, Y., Yu, Z. \& Sun, M. 0000 . Transgenic Amorphophallus konjac expressing synthesized acyl-homoserine lactonase (aiiA) gene exhibit enhanced resistance to soft rot disease. Plant Cell Report, 28: 1847-1855.

Chaudhari, V., Gosai, H., Raval, S. \& Kothari, V. 2004. Effect of certain natural products and organic solvents on quorum sensing in Chromobacterium violaceum. Asian Pacific Journal of Tropical Medicine, 7(1): S204-S211.

Choo, J.H., Rukayadi, Y. \& Hwang, J.K. 2006. Inhibition of bacterial quorum sensing by vanilla extract. Letter in Applied Micro-biology, 42(6): 637-641.

Crepin, A., Cirou, A.M., Barbey, C., Farmer, C., Helias, V., Burini, J.F., Faure, D. \& Latour, X. 2012. $\mathrm{N}$-acyl homoserin lactones in diverse Pectobacterium and Dickeya plant pathogen: diversity, abudance and involvement in virulence. Sensor, 12(3): 3494-3497. 
Czajkowski, R. \& Jafra, S. 2009. Quenching of acyl-homoserine lactone dependent quorum sensing by enzymatic disruption of signal molecules. Acta Biochimica Polonica, 56(1): 1-16.

Defoirdt, T., Boon, N., Bossier, P. \& Verstraete, W. 2004. Disruption of bacterial quorum sensing: an unexplored strategy to fight infections in aquaculture. Aquaculture, 240(14): 69-88.

Dong, Y.H., Xu, J.L., Li, X.C. \& Zang, L.H. 2000. aiiA, a novel enzyme inactivates acyl homoserine-lactone quorum sesing signal and attenuates the virulence of Erwinia caratovora. Proceedings of the National Academy of Sciences, 97(7): 3526-3531.

Dong, Y.H., Gusti, A.R., Zhang, Q., Xu, J.L. \& Zhang, L.H. 2002. Identification of quorum quoenching $\mathrm{N}$-acyl homoserin lactones from Bacillus spesies. Applied and Environmental Microbiology, 68(4): 1754-1759.

Fuqua, C. \& Greenberg, E.P. 2002. Listening in on bacteria acyl-homoserine lactone signaling. Nature Rev., 3: 683-695.

Fitriyah, D., Rusmana, I., Wahyudi, A.T. 2015. Characterization of bacteria producing acyl homoserine lactone (AHL) lactonase for agricultural lands. Advance in Enviromental Biology, 9(8): 140-148.

Gerayeli, N., Ravari, S.B. \& Tarigh S. 2018. Evaluation of the antagonistic potential of Bacillus strains against Pectobacterium carotovorum subsp. carotovorum and their role in the induction of resistance to potato soft rot infection. European Journal of Plant Pathology, 150(4): 1049-1063.

Hoshino, T. 2011. Violacein and related tryptophan metabolites produced by Chromobacterium violaceum: biosynthetic mechanism and pathway for construction of violacein core. Applied Microbiolgy and Biotechnology, 91: 1463-1475.

Huma, N., Shankar, P., Kushwah, J., Bhushan, A., Joshi, J., Mukherjee, T., Raju, S., Purohit, H.J. \& Kalia, V.C. 2011. Diversity and polymorphism in AHL-lactonase gene (aiiA) of Bacillus. Journal Microbiology and Biotechnology, 21: 1001-1011.

Khoiri, S., Damayanti, T.S. \& Giyanto. 2017. Identification of quorum quenching bacteria and its biocontrol potential against soft rot disease bacteria, Dickeya dadantii. AGRIVITA Journal of Agricultural Science, 39(1): 45-55.

Krzyzanowska, D.M., Potrykus, M., Golanowska, M., \& Polonis, K. 2012. Rhizosphere bacteria as potential biocontrol agents against soft rot caused by various Pectobacterium and Dickeya spp. strains. Journal of Plant Pathology, 94(2): 367-378
Lamas, M.A., Ordonez, E.C., Solanilla, E.M., Raposo, R. \& Salazar, O.T., Moreno, A.R., Palenzuela, P.R. 2009. Role of motility and chemotaxis in the pathogenesis of Dickeya dadantii 3937 (ex Erwinia chrysanthemi 3937. Microbiology, 155: 434-442.

Lee, Y.A., Chen, K.P. \& Chang, Y.C. 2002. First report of bacterial soft rot of white flowered calla lily caused by Erwinia chrysanthemi in Taiwan. Plant Disease, 86(11): 1273-1273.

Mansfield, J., Genin, S., Magori, S., Citovsky, V., Sriariyanum, M., Ronald, P., Dow, M., Verdier, V. \& Beer, S.V. 2012. Top 10 plant pathogenic bacteria in molecular plant pathology. Molecular Plant Pathology, 13(6): 614-629.

Marchesi, J.R., Sato, T., Weightman, A.J., Martin, A.T., Fry, J.C., Hiom, S.J. \& Wade, W.G. 1998. Design and evaluation of useful bacteriumspecific primers that amplify genes coding for bacterial 16S rRNA. Applied and Environmental Microbiology, 64(2): 795-799.

Molina, L., Constantinescu, F., Michel, L., Reimmann, C., Duffy, B. \& Défago, G. 2003. Degradation of pathogen quorum-sensing molecules by soil bacteria: a preventive and curative biological control mechanism. FEMS Microbiology Ecology, 45(1): 71-81.

Morohoshi, T., Kato, M., Fukamachi, K., Kato, N. \& Ikeda, T. 2008. N-Acylhomoserine lactone regulates violacein production in Chromobacterium violaceum type strain ATCC12472. FEMS Microbiology Letter, 279: 124-130.

Pan, J., Huanga, T., Yao, F., Huang, Z., Charles, A., Powell, Qiu, S. \& Guana, X. 2008. Expression and characterization of aiiA gene from Bacillus subtilis BS-1. Microbiological Research, 163(6): 711-716.

Raaijmakers, J.M., De Bruijn, I., Nybroe, O. \& Ongena, M. 2010. Natural functions of lipopeptides from Bacillus and Pseudomonas: more than surfactants and antibiotics. FEMS Microbiology Review, 34: 1037-1062.

Reverchon, S. \& Nasser, W. 2013. Dickeya ecology, environment sensing and regulation of virulence programme. Environmental Microbiology Reports, 5(5): 622-636.

Rodriguez, M., Torres, M., Blanco, L., Béjar, V., Sampedro, I. \& Llamas, I. 2020. Plant growthpromoting activity and quorum quenchingmediated biocontrol of bacterial phytopathogens by Pseudomonas segetis strain P6. Scienific Reports, 10: 4121.

Samson, R., Legendre, J.B., Christen, R., Fischer, L., Saux, M., Achouak, W. \& Gardan, L. 2005. Transfer of Pectobacterium chrysanthemi (Burkholder et al., 1953) Brenner I. 1973 and Brenneria paradisiaca to the genus Dickeya gen. nov. as Dickeya chrysanthemi comb. nov and 
Dickeya paradisiaca comb. nov. and delineation of four novel species, Dickeya dadantii sp. nov., Dickeya dianthicola sp. nov., Dickeya dieffenbachiae sp. nov. and Dickeya zeae sp. nov. International Journal of Systematic and Evolutionary Microbiology, 55: 1415-1427.

Sari, P.E., Rusmana, I. \& Akhidya, A. 2016. AHL-lactonase characteristics of Bacillus thuringiensis SGT3g and its effectiveness in inhibiting pathogenicity of Dickeya dadantii. Malaysian Journal of Microbiology, 12(4): 315-321.

Satwika, T.D., Rusmana, I. \& Akhidya, A. 2017. Potensi quorum quenching bakteri filosfer dan rizosfer terhadap Dickeya dadantii. Jurnal AgroBiogen, 13(2): 101-110.
Torres, M., Romeroc, M., Pradoc, S., Dubertc, J., Tahriouia, A, Oteroc, A. \& Lamasa, I. 2013. $\mathrm{N}$-acylhomoserine lactone-degrading bacteria isolated from hatchery bivalve larval cultures. Microbiological Research, 168(9): 547-554.

Wang, L.H., Weng, L.X., Dong, Y.H. \& Zhang, L.H. 2004. Specificity and enzyme kinetics of the quorum-quenching $\mathrm{n}$-acyl homoserine lactone lactonase (AHL-lactonase). The Journal of Biological Chemistry, 279(14): 13645-13651.

Zhang, J., Feng, T., Wang, J., Wang, Y. \& Zhang, X.H. 2019. The mechanisms and applications of Quorum Sensing (QS) and Quorum Quenching (QQ). Journal of Ocean University of China, 18: 1427-1442. 